\title{
Biological residues define the ice nucleation properties of soil dust
}

\author{
F. Conen ${ }^{1}$, C. E. Morris ${ }^{2}$, J. Leifeld ${ }^{3}$, M. V. Yakutin $^{4}$, and C. Alewell ${ }^{1}$ \\ ${ }^{1}$ Institute of Environmental Geosciences, University of Basel, 4056 Basel, Switzerland \\ ${ }^{2}$ INRA, Unité de Pathologie Végétale UR407, 84140 Montfavet, France \\ ${ }^{3}$ Air Pollution/Climate Group, Agroscope Reckenholz-Tänikon Research Station ART, 8046 Zürich, Switzerland \\ ${ }^{4}$ Institute of Soil Science and Agrochemistry, Siberian Branch of the Russian Academy of Sciences, \\ 630099 Novosibirsk, Russia
}

Received: 26 May 2011 - Published in Atmos. Chem. Phys. Discuss.: 10 June 2011

Revised: 7 September 2011 - Accepted: 8 September 2011 - Published: 16 September 2011

\begin{abstract}
Soil dust is a major driver of ice nucleation in clouds leading to precipitation. It consists largely of mineral particles with a small fraction of organic matter constituted mainly of remains of micro-organisms that participated in degrading plant debris before their own decay. Some micro-organisms have been shown to be much better ice nuclei than the most efficient soil mineral. Yet, current aerosol schemes in global climate models do not consider a difference between soil dust and mineral dust in terms of ice nucleation activity. Here, we show that particles from the clay and silt size fraction of four different soils naturally associated with 0.7 to $11.8 \%$ organic carbon (w/w) can have up to four orders of magnitude more ice nucleation sites per unit mass active in the immersion freezing mode at $-12{ }^{\circ} \mathrm{C}$ than montmorillonite, the nucleation properties of which are often used to represent those of mineral dusts in modelling studies. Most of this activity was lost after heat treatment. Removal of biological residues reduced ice nucleation activity to, or below that of montmorillonite. Desert soils, inherently low in organic content, are a large natural source of dust in the atmosphere. In contrast, agricultural land use is concentrated on fertile soils with much larger organic matter contents than found in deserts. It is currently estimated that the contribution of agricultural soils to the global dust burden is less than $20 \%$. Yet, these disturbed soils can contribute ice nuclei to the atmosphere of a very different and much more potent kind than mineral dusts.
\end{abstract}

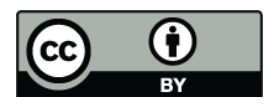

Correspondence to: F. Conen (franz.conen@unibas.ch)

\section{Introduction}

Cloud droplets do not freeze until temperatures drop below about -36 to $-37^{\circ} \mathrm{C}$ (Murray et al., 2010), unless they harbor heterogeneous ice nuclei (IN). The number of IN in the atmosphere correlates well with the number of particles $>0.5 \mu \mathrm{m}$ in diameter, a size range often dominated in the free troposphere by mineral and soil dust (DeMott et al., 2010). IN markedly affect the development of clouds and precipitation. The most efficient naturally occurring IN are proteins on the surface of biological particles. They have the capacity to catalyse freezing at temperatures near $-2{ }^{\circ} \mathrm{C}$ (Maki et al., 1974; Wilson et al., 2006). It has been suggested that all IN active at temperatures warmer than $-10^{\circ} \mathrm{C}$ are of biological origin (Christner et al., 2008; DeMott et al., 2010). Nonbiological IN are typically active only at colder temperatures (DeMott et al., 2010). The study of soil samples, and more precisely of decomposing leaves, first raised the issue of biological ice nucleation (Schnell and Vali, 1972, 1972, 1976) and its association with certain bacteria (Maki et al., 1974). The starting point for this research was in 1968, when G. Vali discovered "that soils having higher contents of organic matter are better nucleators than pure clays or sands" (G. Vali, 1968, cited in Schnell and Vali, 1972). However, in atmospheric modelling, soil dust is considered a purely mineral IN (Lohmann and Diehl, 2006; Hoose et al., 2010a; Diehl and Wurzler, 2010). Representation of biological IN in these models is limited to bacterial cells and fungal spores (Hoose et al., 2010a; Diehl and Wurzler, 2010). These are considered to come principally from plant canopies, and to a lesser degree from soils (Lindemann et al., 1982). Although bacteria and other micro-organisms rarely constitute more than $2 \%(\mathrm{w} / \mathrm{w})$ of all soil organic carbon (Kaiser et al., 1992), ice

Published by Copernicus Publications on behalf of the European Geosciences Union. 
Table 1. Origin of samples (MAT = mean annual temperature) and their carbon content (in $\% \mathrm{w} / \mathrm{w})$.

\begin{tabular}{cllrrrr}
\hline Sample & Region & Coordinates & Altitude & MAT $\left({ }^{\circ} \mathrm{C}\right)$ & \multicolumn{2}{c}{ Organic C content $(\%)$} \\
\cline { 3 - 6 } & & & & & bulk soil & $<15 \mu \mathrm{m}$ \\
\hline A & Western Mongolia & $46^{\circ} 19^{\prime} \mathrm{N} ; 95^{\circ} 04^{\prime} \mathrm{E}$ & $976 \mathrm{~m}$ & -0.1 & 0.2 & 0.7 \\
B & Southern Germany & $47^{\circ} 38^{\prime} \mathrm{N} ; 07^{\circ} 40^{\prime} \mathrm{E}$ & $300 \mathrm{~m}$ & 9.8 & 2.9 & 5.1 \\
C & Central Hungary & $46^{\circ} 58^{\prime} \mathrm{N} ; 19^{\circ} 33^{\prime} \mathrm{E}$ & $125 \mathrm{~m}$ & 10.4 & 2.7 & 11.8 \\
D & Central Yakutia & $62^{\circ} 28^{\prime} \mathrm{N} ; 126^{\circ} 01^{\prime} \mathrm{E}$ & $240 \mathrm{~m}$ & -9.5 & 3.3 & 5.4 \\
\hline
\end{tabular}

nucleation activity can be retained by dead cells (under certain conditions) and certain types of cell fragments. Furthermore, IN have also been found to be associated with certain plants and fungi (Lee et al., 1995), and these might also contribute to the soil organic matter. In the particle size ranges of clay and silt, the vast majority of biological material consists of more or less decomposed biological residues (Guggenberger et al., 1994) and is part of so-called organo-mineral complexes (Chenu and Plante, 2006). Even in soils with a small organic matter content (1-2\% organic carbon (w/w)) up to $50 \%$ of the particle surface area can be covered with such residues (Kahle et al., 2002). Our focus is on the extent to which these small amounts of biological residues may be responsible for the IN activity within soil dust.

\section{Materials and methods}

Air dried soil samples from the top $10 \mathrm{~cm}$ on patches of grassland (Table 1) were first sieved dry $(<63 \mu \mathrm{m})$, then wet $(<15 \mu \mathrm{m})$. Wet sieving is the standard technique to separate different particle size fractions in soil. The dried soil is immersed in water on a sieve of a given mesh and water is rinsed through, taking with it the particles that are smaller than the mesh size. The procedure releases some dissolved organic carbon that may be re-distributed among particle size fractions. In a study on over 100 soils of different origin, Zimmermann et al. (2007) measured an average loss in this form of dissolved organic carbon of $1.5 \%$ of the total organic carbon in soil by wet sieving. Thus, the vast majority of the organic carbon distribution of the undisturbed sample remains present. We call the fraction $<15 \mu \mathrm{m}$ "soil dust". Particle size analysis by laser diffraction (Mastersizer X, Malvern Instruments, Worcestershire, UK) revealed that in all soil dusts, particles smaller than $3 \mu \mathrm{m}$ occupy a total volume fraction of 0.2 to 0.3 and particles $<10 \mu \mathrm{m}$ occupy a total volume fraction of about two-thirds. Assuming particles are spherical and have a density of $2.6 \mathrm{~g} \mathrm{~cm}^{-3}$, we estimate from the detailed particle size anaylsis the total number of particles $>0.5 \mu \mathrm{m}$ diameter in $1 \mu \mathrm{g}$ of soil dust to be around $8 \times 10^{4}$.

We tested ice nucleation efficiency by immersion freezing, which has been estimated theoretically to represent the vast majority of nucleation events (Hoose et al., 2010b). By indirect observational means, Westbrook and Illingworth (2011) come to a similar conclusion. Initial tests indicated that two soils were much more active than the others. Therefore, the suspensions of the most active soils had to be diluted with distilled water before they could be characterized. Final concentrations were 0.1 (soil D), 2 (soil C) and 10 (soils A, B) $\mu \mathrm{g} \mathrm{ml}^{-1}$. To better characterize the warmer end of the temperature range, all soil dusts, untreated and heat treated, were in addition tested at 5-times higher concentrations, respectively. To characterise the lower end of the temperature scale, soil D was also tested in a lower, third concentration $\left(0.02 \mu \mathrm{g} \mathrm{ml}^{-1}\right)$. For some temperature steps, data from more than one concentration were available. This applies to all soils. The overlap of data between different concentrations was in at least one, at most seven, temperature steps. Such duplicate (triplicate) data at one temperature step were logaveraged.

From each soil suspension 54 drops, consisting of $50 \mu \mathrm{l}$ aliquots in $0.5 \mathrm{ml}$ Eppendorf safe lock tubes, were exposed to decreasing temperatures $\left(-4\right.$ to $\left.-15^{\circ} \mathrm{C}\right)$ in a water bath cooling at a rate of $1^{\circ} \mathrm{C}$ in $3 \mathrm{~min}$. The number of frozen tubes was inspected visually after each cooling step. The cumulative number of ice nucleation sites active at the observation temperature or warmer per mass of soil dust $\left(K_{T}\right)$ was calculated similar to Vali (1971, Eq. (13), mass of soil dust per drop $(d)$ substituted for volume of drop $(V))$ as:

$K_{T}=\left[\ln \left(N_{\text {total }}\right)-\ln \left(N_{\text {unfrozen }}\right)\right] / d$

where $N_{\text {total }}$ is the total number of drops (54), $N_{\text {unfrozen }}$ is the number of drops still unfrozen (liquid) at the observation temperature, and $d$ is the mass of soil dust per drop.

Although we clearly can not determine which approach is more appropriate, we believe this time-independent model is justified here because of the heterogenous surface properties of soil dust samples that probably provide few sites with a high probability of nucleating ice (Vali, 2008). The timeindependent approach also makes our data comparable to previous studies on IN associated with leaf litter and soil (e.g. Schnell and Vali, 1972, 1973, 1976). Additional measurements were made with a suspension of montmorillonite $\left(10 \mu \mathrm{g} \mathrm{ml}^{-1} ; 50 \mu \mathrm{g} \mathrm{ml}^{-1}\right.$ ) (Montmorillonite (aluminium pillared clay), Sigma Aldrich, CAS No. 139264-88-3) and with 5 sets of blanks, each set consisting of 54 drops $(50 \mu \mathrm{l})$ distilled water in the same type of tube as for the other samples. 


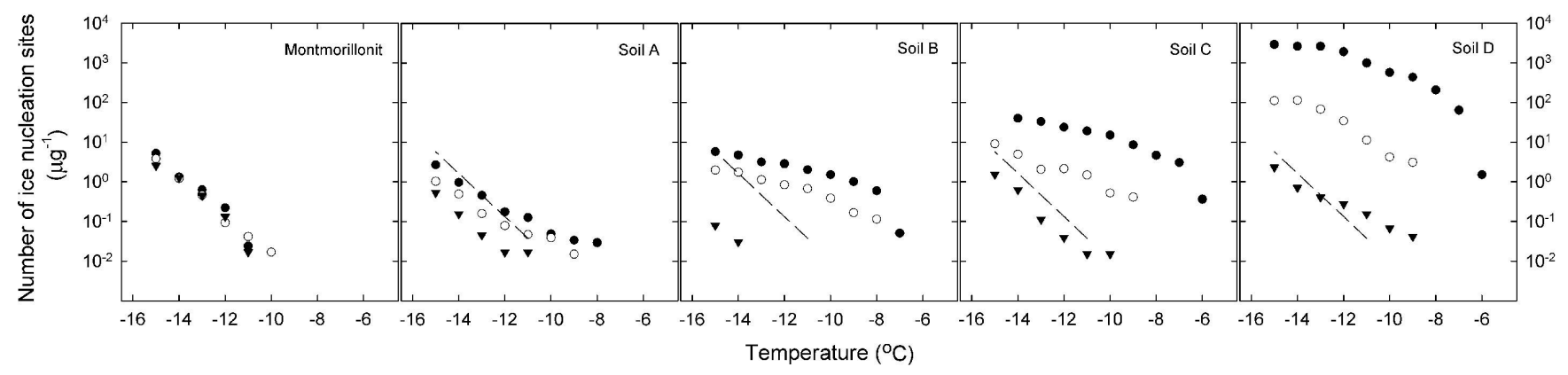

Fig. 1. Freezing properties of montmorillonite and dust particles $(<15 \mu \mathrm{m})$ from different soils $(A, B, C, D)$ immersed in distilled $\mathrm{H}_{2} \mathrm{O}$. Initial numbers of ice nucleation sites $(\bullet)$, numbers of ice nucleation sites still active after heating (o), and numbers of ice nucleation sites remaining after removal of organic matter $(\nabla)$ are shown. Dashed lines indicate the curve for untreated montmorillonite, for comparison.

Only in one blank set did a tube freeze at $>-15^{\circ} \mathrm{C}$. So, no background was subtracted from the results with soil suspensions. Numbers of frozen samples at a particular temperature were only considered when $>1$. To test the contribution of heat-sensitive components of organic matter to the nucleation activity, samples were then exposed for $10 \mathrm{~min}$ to temperatures $\sim 100^{\circ} \mathrm{C}$ in a water bath and tested again (heat treated samples). Freezing nucleation properties of the mineral phase were determined for samples where the organic carbon had been removed by oxidation to $\mathrm{CO}_{2}$ via exposure to $\mathrm{H}_{2} \mathrm{O}_{2}(35 \%)$. Because these samples showed much lower activity in initial tests, they were all tested at concentrations of 10 and $50 \mu \mathrm{g} \mathrm{ml}^{-1}$. Organic carbon content $(\mathrm{w} / \mathrm{w})$ of the dust fraction was determined by dry combustion using an elemental analyzer (Flash-EA 1112, Thermo Electron, Milano, Italy).

\section{Results and discussion}

To assess the contribution of biological residues to the IN efficiency of soil dust, we conducted immersion freezing tests with particles in the clay and finer silt fractions $(<15 \mu \mathrm{m})$ from soils in Western Mongolia (A), Germany (B), Hungary (C) and Eastern Siberia (D), harbouring 0.7, 5.1, 11.8 and $5.4 \%$ organic carbon (w/w), respectively (Table 1$)$. The three soil dusts with $>5 \%$ organic carbon content were much more efficient IN than montmorillonite, the nucleation properties of which are often used to represent those of mineral dusts in modelling studies (Fig. 1). At $-12{ }^{\circ} \mathrm{C}$, for example, the number of ice nucleation sites per $\mu \mathrm{g}$ of dust was 0.2 for montmorillonite and soil dust A, but 3, 24, and 1910 for soil dusts B, $\mathrm{C}$, and $\mathrm{D}$, respectively. At $-8^{\circ} \mathrm{C}$, the number of ice nucleation sites per $\mu \mathrm{g}$ of montmorillonite was below the detection threshold, but was 0.03, 0.6, 5 and 206 for soil dusts A, B, $\mathrm{C}$ and $\mathrm{D}$, respectively. At this temperature we assume that the active ice nucleation sites are biological residues. Based on data from the literature for the total soil organic carbon content $\left(1.5 \times 10^{18} \mathrm{~g}\right)$ and the global bacterial population of soil $\left(2.6 \times 10^{29}\right.$ bacterial cells (Whitman et al., 1998)) we estimated if intact bacteria could account for some of these ice nucleation sites. We assume that intact bacterial cell number density is proportional to organic carbon content, so there would be $1.7 \times 10^{5}$ intact cells associated with $1 \mu \mathrm{g}$ organic carbon in soil. For this calculation we also take into account that the known species of ice nucleation active bacteria, such as Pseudomonas syringae or P. borealis (Wilson et al., 2006), constitute a very small fraction of soil bacterial communities $(<0.1 \%)$. Furthermore, at $-8^{\circ} \mathrm{C}$, the fraction of intact cells that produce ice nuclei does not exceed 0.01 for most strains. Given these assumptions, intact bacteria would account for $0.01,0.1,0.2$ and 0.1 ice nucleation sites $\mu \mathrm{g}^{-1}$ of soil dust $\mathrm{A}, \mathrm{B}, \mathrm{C}$ and D respectively. Air drying reduces the number of bacteria. Furthermore, one of the main IN active species, Pseudomonas syringae, is almost never detectable in soils, even in fresh soils. This plant pathogen has no extended soil phase (Goodnow et al., 1990, and references therein). Therefore, we think the estimates of small numbers of intact IN active bacteria in our samples are still optimistically high. Hence, the contribution of intact bacteria to the IN associated with these soils would seem to be negligible.

Although dust $\mathrm{D}$ has just as much organic carbon as dust $B$, the number of ice nucleation sites per unit mass of this dust was substantially larger. So, probably the nature of the organic matter and processes contributing to its preservation play a role in this difference, not just the quantity. Soil D is from an environment where the mean annual temperature is $-9.5^{\circ} \mathrm{C}$, whereas soil B experiences a mean annual temperature of $+9.8^{\circ} \mathrm{C}$. Numbers of IN in leaf litter from cold environments are known to be larger, and onset freezing temperatures are higher, than in leaf litter from warm regions (Schnell and Vali, 1973). IN active sites in plants, bacteria and other micro-organisms are proteins (Wolber et al., 1986; Morris et al., 2004) and proteins are well preserved when sorbed to mineral surfaces (Kleber et al., 2007). Properties of leaf-derived and microbial IN in the respective climate zones may be transferred to organic coatings of mineral soil particles in these zones. This could explain the much 


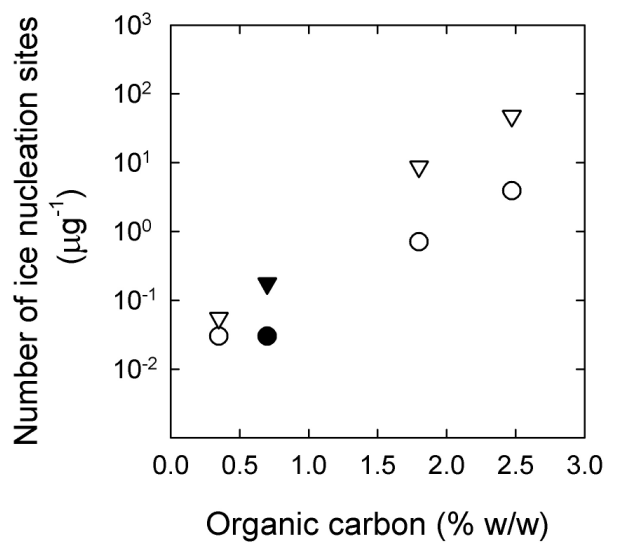

Fig. 2. Relationship between the number of ice nucleation sites and soil organic carbon (w/w) in soil dusts $(<15 \mu \mathrm{m})$ from Western Mongolia. Closed symbols are for data from soil A in Fig. 1. Open symbols are for soil dusts collected between 9 and $313 \mathrm{~km}$ from soil A. Circles and triangles show the number of ice nucleation sites active at $-8^{\circ} \mathrm{C}$ and $-12^{\circ} \mathrm{C}$, respectively.

larger number of ice nucleation sites per unit mass in soil D compared to soil C, although D has less organic carbon content than $\mathrm{C}$ in the analysed fine fraction (Table 1). There is probably no simple global relation between organic carbon content and the number of ice nucleation sites per unit mass of soil dust. Nevertheless, within a particular region, this number may well correlate with the amount of biological residues associated with mineral dust. Further samples from Western Mongolia, but with different organic carbon contents than soil A, support such a presumption (Fig. 2). Within this region, the number of ice nucleation sites active at -8 and $-12{ }^{\circ} \mathrm{C}$ seems to increase by roughly one order of magnitude with each percent increase in organic carbon (w/w). Earlier data by Schnell and Vali (1972, Fig. 1) suggest an increase in the number of IN active at $-10^{\circ} \mathrm{C}$ by three orders of magnitude from about 0.1 to $10 \%$ soil organic content.

By heat treating (Christner et al., 2008) the particles of the soil dusts, we revealed that the agent responsible for the large number of ice nucleation sites active above $-10^{\circ} \mathrm{C}$, and in some cases even colder, was most likely proteinaceous rather than a mineral. Heating destroys the configuration, and thereby the function, of many biological molecules and in particular proteins which constitute the most active biological IN known. The very small amounts of soil dust in suspension (few $\mu \mathrm{g} \mathrm{ml}^{-1}$ ) make it improbable that dissolution of organic material during heat treatment could have changed the aqueous phase to a degree where it might have caused a freezing point depression. As expected, the ice nucleation activity of the purely mineral sample, montmorillonite, was little affected by heating. Soil dust A, which is associated with only $0.7 \%$ organic carbon $(\mathrm{w} / \mathrm{w})$ behaved similarly to montmorillonite. However, soil dusts B, C, and
D with $>5 \%$ organic carbon (w/w) lost 70, 91 and $98 \%$ of their initial activity at $-12^{\circ} \mathrm{C}$ after heating. Activity at $-8^{\circ} \mathrm{C}$ was no longer detected after heating in soil dusts $\mathrm{A}, \mathrm{C}$ and $\mathrm{D}$. Soil dust B lost $82 \%$ of its initial activity at $-8^{\circ} \mathrm{C}$ by heating. When samples were treated with $\mathrm{H}_{2} \mathrm{O}_{2}$ to strip them of biological residues via oxidation, IN activity was further reduced either close to, or below, that of montmorillonite, which itself was little affected by the treatment. Treatment with $\mathrm{H}_{2} \mathrm{O}_{2}$ is a common procedure to oxidize organic matter from soil samples for subsequent analysis of the remaining minerals. These results illustrate that the IN activity of soils containing a certain level of biological residues is far greater than that of the basic mineral constituents composing the soil dust. They also suggest a direct role of the biological residues associated with mineral particles acting as IN although the actual source, or sources, of the organic ice nucleation sites remains to be identified. A loss of IN activity in the mineral phase due to the treatments of the samples seems unlikely, although reactions of mineral complexes in soil dusts that are not pure phases can not be ruled out. Perhaps more important than the increase in the number of ice nucleation sites per unit mass at any particular temperature is the upward shift in the onset of freezing caused by the biological residues. Observations over the Amazon seem to suggest that, despite small number concentrations, biological particles dominate the ice-nucleus population at warmer temperatures (Prenni et al., 2009). In our experiments it reaches into the range of temperatures where a process of multiplication of ice by shattering of crystals can be active in clouds $\left(-8^{\circ} \mathrm{C}\right.$ or warmer) (Hallett and Mossop, 1974).

\section{Conclusion}

While we can confidently state that small amounts of biological residues can greatly enhance the number of ice nucleation sites from soils active at a certain temperature and shift onset of freezing to warmer temperatures, there are still a number of questions to be answered before the atmospheric implications of these findings may be quantified. A critical point is to know how the ice nucleation sites are distributed among single particles in the atmosphere. From our particle size analysis we estimate that $1 \mu \mathrm{g}$ of analysed soil dust contains on average $8 \times 10^{4}$ particles $>0.5 \mu \mathrm{m}$ in diameter. So, even in the most active soil $\mathrm{D}$, no more than 1 in about 400 particles $>0.5 \mu \mathrm{m}$ is likely to carry a site that is IN active at $-8^{\circ} \mathrm{C}$ and less than 1 in 40 carries a site active at $-12^{\circ} \mathrm{C}$. Particle size distribution of natural soil dust lifted to cloud height will not necessarily be the same as in our samples, where the largest particles were up to $15 \mu \mathrm{m}$ in diameter. From soil science we know that biological residue concentrations $(w / w)$ in soil increase with decreasing particle size (Kahle et al., 2002). So, for the same mass, a collection of small particles will harbour a larger amount of biological residues than a collection of larger particles. The smaller a particle, 
the greater the likelihood it is transported to cloud heights. Consequently, air movements preferentially transport small soil particles, which carry above average loads of biological residues (Hoffmann et al., 2008), so probably also a greater number of IN per unit mass than is found in the bulk soil.

Recent in situ detection of cloud ice crystal residues at high altitudes revealed that $60 \%$ of the dust particles contained biological material, which may have led to increased ice-nucleation efficiency (Pratt et al., 2009). Significant effects on stratiform mixed-phase clouds have been observed in simulations when parameters for kaolinite (a clay that is less IN active than montmorillonite) are used (Lohmann and Diehl, 2006). The same simulation comparing montmorillonite with biologically IN-activated soil particles would be a worthwhile exercise to re-evaluate the anthropogenic indirect aerosol effect caused by landuse or landuse change. Overgrazing of natural steppes in Inner Mongolia leads to wind erosion releasing soil particles to the atmosphere with 3-4\% organic carbon (w/w) (Hoffmann et al., 2008). Tillage operations on arable soils can multiply the amount of dust emissions caused by wind erosion in temperate regions (Goossens et al., 2001), and high anthropogenically induced wind erosion rates often affect soils rich in organic matter (Moon, 2005; Galic et al., 2009). The effect of IN associated with these dust emissions on cloud processes might be considerably larger than expected from their currently-estimated contribution of less than $20 \%$ to the global dust burden (Forster et al., 2007).

Acknowledgements. We thank A. N. Puchnin, Ch. Lhagvasuren and V. P. Baranov for the samples from Eastern Siberia and from Western Mongolia, B. Ritter for the particle size determination, and M. Rollog for the $\mathrm{C}$ analyses. Thank you to Annina Gysel and Marianne Caroni for the drop freeze tests with additional samples from Western Mongolia (Fig. 2).

Edited by: D. Knopf

\section{References}

Chenu, C. and Plante, A. F.: Clay-sized organo-mineral complexes in a cultivation chronosequence: revisiting the concept of the 'primary organo-mineral complex', Eur. J. Soil Sci. 57, 596607, 2006.

Christner, B. C., Morris, C. E., Foreman, C. M., Cai, R., and Sands, D. C.: Ubiquity of biological ice nucleators in snowfall, Science, 319, 1214, doi:10.1126/science.1149757, 2008.

DeMott, P. J. and Prenni, A. J.: New Directions: Need for defining the numbers and sources of biological aerosols acting as ice nuclei, Atmos. Environ., 44, 1944-1945, 2010.

DeMott, P. J., Prenni, A. J., Liu, X., Kreidenweis, S. M., Petters, M. D., Twohy, C. H., Richardson, M. S., Eidhammer, T., Rogers, D. C.: Predicting global atmospheric ice nuclei distributions and their impacts on climate, P. Natl. Acad. Sci. USA, 107, 1121711222, 2010.
Diehl, K. and Wurzler, S.: Air parcel model simulations of a convective cloud: Bacteria acting as immersion ice nuclei, Atmos. Environ. 44, 4622-4628, 2010.

Forster, P., Ramaswamy, V. Artaxo, P., Berntsen, T., Betts, R., Fahey, D. W., Haywood, J., Lean, J., Lowe, D. C., Myhre, G., Nganga, J., Prinn, R., Raga, G., Schulz M., and Van Dorland, R.: Changes in Atmospheric Constituents and in Radiative Forcing, in: Climate Change 2007: The Physical Science Basis. Contribution of Working Group I to the Fourth Assessment Report of the Intergovernmental Panel on Climate Change, edited by: Solomon, S., Qin, D., Manning, M., Chen, Z., Marquis, M., Averyt, K. B., Tignor, M., and Miller, H. L., Cambridge University Press, Cambridge, United Kingdom and New York, NY, USA, 2007.

Galic, Z., Orlovic, S., Galovic, V., Poljakivic-Pajnik, L., Pap, P., Vasic, V.: Challenges of land use change and land protection in Vojvodina, Afr. J. Agric. Res., 4, 1566-1573, 2009.

Goodnow, R. A., Harrison, M. D., Morris, J. D., Sweeting, K. B., and Laduka, R. J.: Fate of ice nucleation-active Pseudomonas syringae strains in alpine soils and waters and in synthetic snow samples, Appl. Environ. Microbiol. 56, 2223-2227, 1990.

Goossens, D., Gross, J., and Spaan, W.: Aeolian dust dynamics in agricultural land areas in Lower Saxony, Germany, Earth Surf Process. Landforms., 26, 701-720, 2001.

Guggenberger, G., Christensen, B., and Zech, W.: Land-use effects on the composition of organic matter in particle-size separates of soil .1. Lignin and carbohydrate signature, Eur. J. Soil Sci. 45, 449-458, 1994.

Hallett, J. and Mossop, S. C.: Production of secondary ice particles during the riming process Nature, 249, 26-28, 1974

Hoffmann, C., Funk, R., Li, Y., and Sommer, M.: Effect of grazing on wind driven carbon and nitrogen ratios in the grasslands of Inner Mongolia, Catena, 75, 182-190, 2008.

Hoose, C., Kristjansson, J. E., and Burrows, S. M.: How important is biological ice nucleation in clouds on a global scale?, Environ. Res. Lett., 5, 024009, doi:10.1088/1748-9326/5/2/024009, 2010a.

Hoose, C., Kristjansson, J. E., Chen, J.-P., and Hazra, A.: A classical-theory-based parametrization of heterogeneous ice nucleation by mineral dust, soot and biological particles in a global climate model, J. Atmos. Sci. 67, 2483-2503, 2010 b.

Kahle, M., Kleber, M., and Jahn, R.: Carbon storage in loess derived surface soils from Central Germany: Influence of mineral phase variables, J. Plant Nutr. Soil Sci., 165, 141-149, 2002.

Kaiser, E.-A., Mueller, T., Joergensen, R. G., Insam, H., and Heinemeyer, O.: Evaluation of methods to estimate the soil microbial biomass and the relationship with soil texture and organic matter, Soil Biol. Biochem., 24, 675-683, 1992.

Kleber, M., Sollins, P., and Sutton, R.: A conceptual model of organo-mineral interactions in soils: self-assembly of organic molecular fragments into zonal structures on mineral surfaces, Biogeochemistry, 85, 9-24, 2007.

Lee, R. E.,Warren, G. J., and Gusta, L. V.: Biological Ice Nuclation and Its Applications, APS Press, St. Paul, Minnesota, USA, 1995.

Lindemann, J., Constantinidou, H. A., Barchet, W. R., and Upper, C. D.: Plants as sources of airborne bacteria, including ice nucleation-active bacteria, Appl. Environ. Microbiol., 44, 10591063, 1982. 
Lohmann, U. and Diehl, K.: Sensitivity studies of the importance of dust ice nuclei for the indirect aerosol effect on stratiform mixedphase clouds, J. Atmos. Sci., 63, 968-982, 2006.

Maki, L. R., Galyan, E. L., Chang-Chien, M.-M., and Caldwell, D. R.: Ice nucleation induced by Psuedomonas syringae, Appl. Microbiol., 28, 456-459, 1974.

Moon, D.: The environmental history of the Russian steppes: Vasilii Dokuchaev and the harvest faillure of 1891, T. Roy. Hist. Soc., 15, 149-174, 2005.

Morris, C. E., Georgakopoulos, D. G., and Sands, D. C.: Ice nucleation active bacteria and their potential role in precipitation, J. Physiques IV France, 121, 87-103, 2004.

Murray, B. J., Broadley, S. L., Wilson, T. W., Bull, S. J., Wills, R. H., Christenson, H. K., and Murray, E. J.: Kinetics of the homogeneous freezing of water, Phys. Chem. Chem. Phys. 12, 10380-10387, 2010.

Pratt, K. A., DeMott, P. J., French, J. R., Wang, Z., Westphal, D. L., Heymsfield, A. J., Twohy, C. H., Prenni, A. J., and Prather, K. A.: In situ detection of biological particles in cloud ice-crystals, Nat. Geosci., 2, 398-401, 2009.

Prenni, A. J., Petters, M. D., Kreidenweis, S. M., Heald, C. L., Martin, S. T., Artaxo, P., Garland, R. M., Wollny, A. G., and Pöschl, U.: Relative roles of biogenic emissions and Saharan dust as ice nuclei in the Amazon basin, Nat. Geosci., 2, 402-405, 2009.

Schnell, R. C. and Vali, G.: Atmospheric ice nuclei from decomposing vegetation, Nature, 236, 163-165, 1972.
Schnell, R. C. and Vali, G.: Worldwide souce of leaf derived freezing nuclei, Nature, 246, 212-213, 1973.

Schnell, R. C. and Vali,G.: Biogenic Ice Nuclei: Part I. Terrestrial and Marine Sources, J. Atmos. Sci., 33, 1554-1564, 1976.

Vali, G.: Quantitative evaluation of experimental results on heterogeneous freezing nucleation of supercooled liquids, J. Atmos. Sci., 28, 402-409, 1971.

Vali, G.: Repeatability and randomness in heterogeneous freezing nucleation, Atmos. Chem. Phys. 8, 5017-5031, 2008.

Westbrook, C. D. and Illingworth, A. J.: Evidence that ice forms primarily in supercooled liquid clouds at temperatures $>-27^{\circ} \mathrm{C}$, Geophys. Res. Lett. 38, L14808, doi:10.1029/2011GL048021, 2011.

Whitman, W. B., Coleman, D. C., Wiebe, W. J.: Prokaryotes: The unseen majority, Proc. Natl. Acad. Sci. USA, 95, 6578-6583, 1998.

Wilson, S. L., Kelley, D. L., and Walker, V. K.: Ice-active characteristics of soil bacteria selected by ice-affinity, Environ. Microbiol., 8, 1816-1824, 2006.

Wolber, P. K., Deininger, C. A., Southworth, M. W., Vandekerckhove, J., Van Montagu, M., and Warren, G. J.: Identification and purification of a bacterial ice-nucleation protein, P. Natl. Acad. Sci. USA, 83, 7256-7260, 1986.

Zimmermann, M., Leifeld, J., Schmidt, M. W. I., Smith, P., and Fuhrer, J.: Measured soil organic matter fractions can be related to pools in the RothC model. Eur. J. Soil Sci. 58, 658-667, 2007. 